an elevation of about $1200 \mathrm{~m}$. On the basis of the ice-thickness map and existing surface topographical information, subglacial water potentials have been calculated by the method described by Björnsson (1982). The results are being analysed. A new surface topographical map based on aerial photographs from 1985 is under preparation to analyse the changes with time of the surface features.

\title{
References
}

Björnsson, H. 1982: Drainage basins on the Vatnajökull mapped by radio echo sounding. Nordic $\mathrm{Hy}$ drol. 13, 213-232.

Braithwaite, R. J. \& Thomsen, H. H. 1984: Runoff conditions at Paakitsup akuliarusersua, Jakobshavn estimated by modelling. Grønlands geol. Unders., Gletscher-hydrol. Meddr 84/3, 22 pp.

Reeh, N. 1983: Ikke-stationær beregningsmodel for Indlandsisens randzone. Grønlands geol. Unders., Gletscher-hydrol. Meddr 83/7, $81 \mathrm{pp}$.

Reeh, N. \& Thomsen, H. H. 1986a: Stable isotope studies on the Greenland ice-sheet margin. Rapp. Grønlands geol. Unders. 130, 108-114.

Reeh, N. \& Thomsen, H. H. 1986b: Model for simulering af ilt-isotop variationen i smeltevandsafstrømningen fra Indlandsisens rand ved Pâkitsup akuliarusersua, Jakobshavn. Grønlands geol. Unders., Gletscher-hydrol. Meddr 86/1, 34 pp.

Thomsen, H. H. 1983: A glaciological field and mapping programme in connection with hydropower, West Greenland. Rapp. Grønlands geol. Unders. 115, 102-107.

Thomsen, H. H. 1984: Glaciological reconnaissance, mass balance measurements and mapping programmes in connection with Greenland hydropower. Rapp. Grønlands geol. Unders. 120, 95-99.

Thomsen, H. H. 1985: Glaciological field work and remote sensing in connection with hydropower investigations, West Greenland. Rapp. Grønlands geol. Unders. 125, 95-99.

Thomsen, H. H. \& Braithwaite, R. J. 1985: Estimation of runoff for proposed hydropower stations near Jakobshavn and Christianshåb, West Greenland. Rapp. Grønlands geol. Unders. 125, 100-103.

Thomsen, H. H. \& Reeh, N. 1986: Glaciological investigations at the margin of the Inland Ice northeast of Jakobshavn, West Greenland. Rapp. Grønlands geol. Unders. 130, 102-108.

Thorning, L., Thomsen, H. H. \& Hansen, E. 1986: Geophysical investigations at the Inland Ice margin of the Pâkitsoq basin, central West Greenland. Rapp. Grønlands geol. Unders. 130, 114-121.

\section{Electromagnetic reflection survey 1986 at the Inland Ice margin of the Pâkitsoq basin, central West Greenland}

\author{
Leif Thorning and Egon Hansen
}

The first successful application of electromagnetic reflection (EMR) techniques for determination of ice thickness in the outermost margin of the Inland Ice adjacent to the Pâkitsoq basin took place in July 1985 (Thorning et al., 1986). Although the survey was planned as a series of experiments to examine why previous attempts had not worked, the EMR data acquired were of very good quality and could be compiled into a preliminary map of ice thickness and a map of the subglacial topography over part of the region. Thus, by early 1986 it 
was known that the method worked and could be compiled through to the final product. With the increasing interest in this region, which is the planned location of the first hydroelectric power plant in Greenland, it was necessary to return in 1986 to survey the area in greater detail and to extend the coverage to the east. This note describes the field work carried out in April 1986 and the subsequent compilation and analysis of the combined EMR data sets from 1985 and 1986.

\section{Helicopter-borne EMR survey in April 1986}

Some areas surveyed in July 1985 did not yield good reflections at all, and reflections sometimes suffered from a lack of definition which could be attributed to large amounts of water in or on the ice in July, completely scattering radar signals. To avoid this, the 1986 operation was carried out in a three week period in April when the ice was still frozen. Although the unstable weather caused problems it was possible to carry out the planned work within the time available.

The instrumentation was largely the same as in 1985, but an event marker was added and the replay and production facilities were significantly improved by the use of an automatic micoprocessor controlled photosystem with a high quality camera allowing much better resolution of the EMR data in hard copies. Another significant addition was the use of a line-ofsight local navigation system borrowed from Grønlands Tekniske Organisation (GTO). GTO also paid the cost of the participation of Bo Madsen (GTO) who took care of the deployment of four remote stations and calculated the preliminary positions in the field and later the final UTM coordinates from navigational data recorded on tape during flights. This made it possible to operate further away from the margin of the Inland Ice. The system could not give inflight information to the pilot, and signals from the remote stations were not always received because of the very low flight altitude of $10 \mathrm{~m}$ over the ice surface, but accurate positions were subsequently calculated for more than $80 \%$ of the data, and the positions of the remaining data could be interpolated with a fairly high degree of accuracy. More survey lines could be flown because it was possible to make measuring flights in directions other than those towards the margin of the Inland Ice. A Bell 206 Jetranger (OY-HBF) was used for the measuring flights. A fuel depot was flown out to the camp at lake 187, Pâkitsoq, for two to three refuelling stops per measuring flight.

Thus the EMR data recorded in 1986 were even better than the data obtained in 1985; the flight lines were longer and well determined, although the lack of inflight feedback of navigational data to the pilot did result in significant deviations from planned flight lines. For most of the data the reflections were more clearly defined and more continuous than in 1985 . Fig. 1 shows the total data coverage from both years.

\section{Processing of EMR data from 1985 and 1986}

The processing of the EMR data was planned and executed specifically to produce maps of ice thickness and subglacial relief of the margin of the Inland Ice. This goal together with narrow time limits determined the degree of detail in the analysis of the data.

Photo profiles of the EMR data were produced from the data recorded on video tapes during the measuring flights. A new automatic replay facility was constructed using an HP85 mi- 


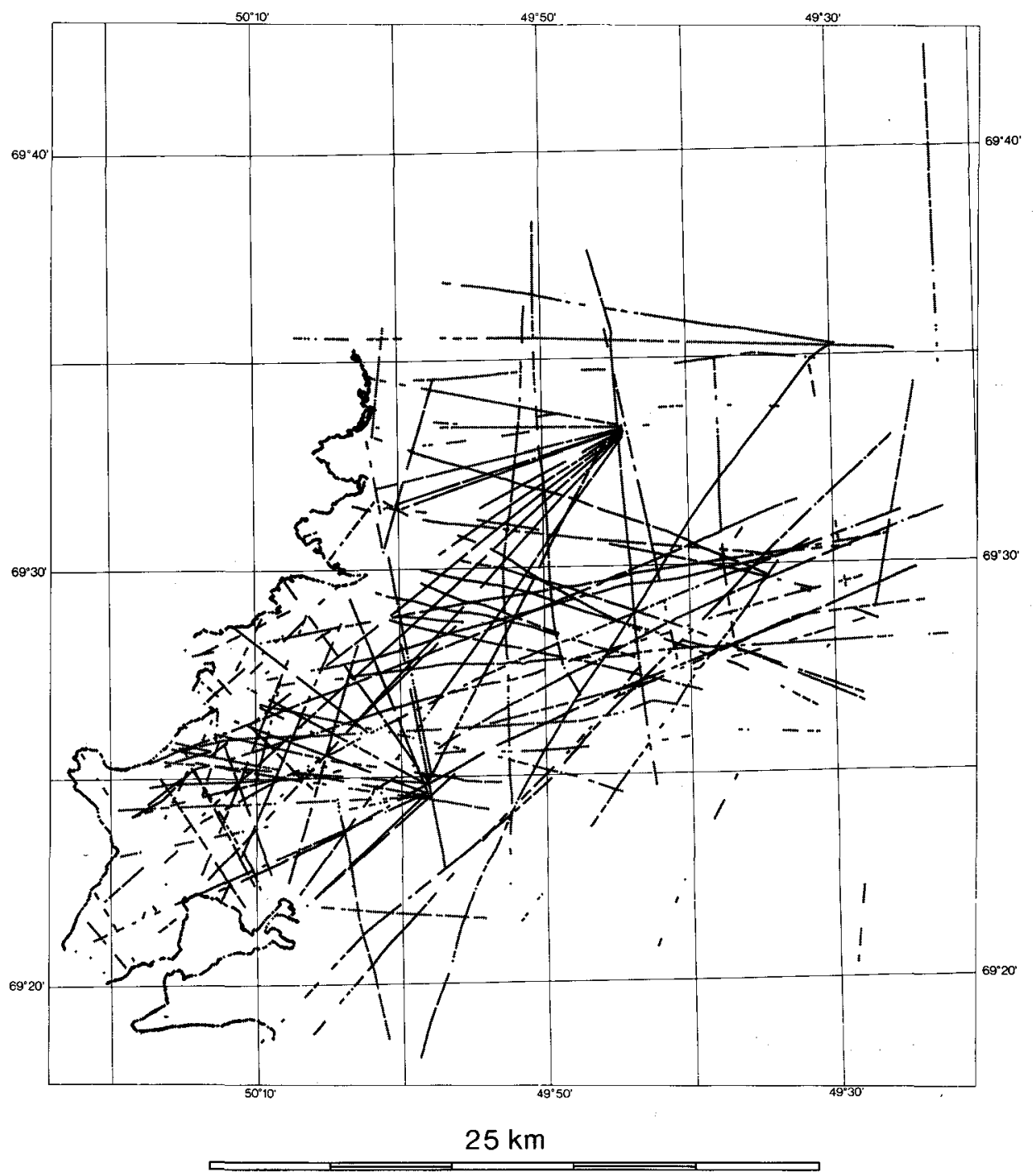

Fig. 1. Positions of averaged, migrated EMR data points along profiles from 1985 and 1986 inland from Sermeq avangnardleq. These ice thickness data together with the marginal points of the ice form the basis of the ice thickness map.

crocomputer to control a high quality camera. These photos were mounted together into continuous profiles and significant EMR data were digitized as segments of reflectors. The digitized EMR data were then merged with navigational data to form a data base of ice thicknesses (two-way travel time) related to specific locations (UTM coordinates) along profiles. Relevant administrative information about the data is also maintained in the data base throughout the entire processing process. 

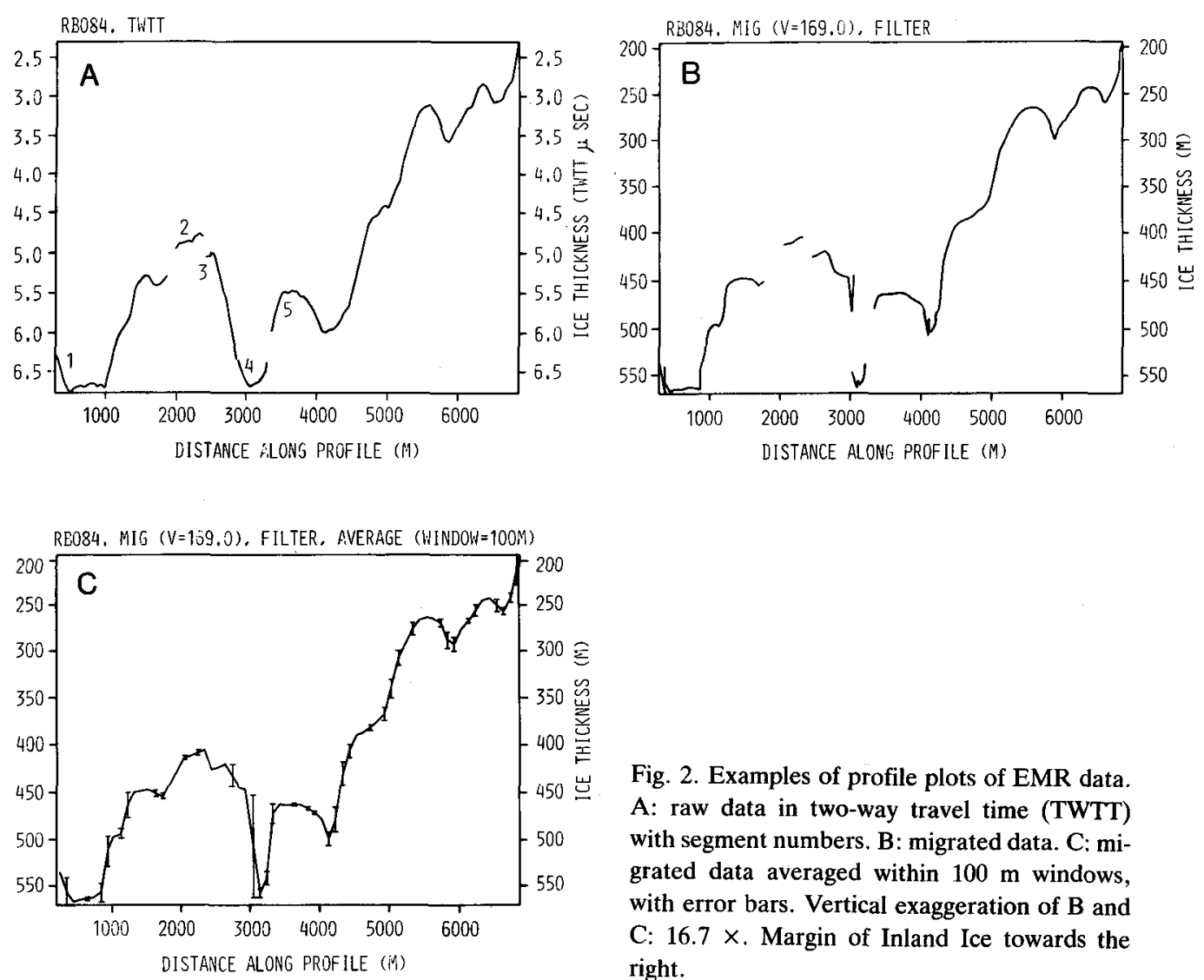

Fig. 2. Examples of profile plots of EMR data. A: raw data in two-way travel time (TWTT) with segment numbers. B: migrated data. C: migrated data averaged within $100 \mathrm{~m}$ windows, with error bars. Vertical exaggeration of $B$ and C: $16.7 \times$. Margin of Inland Ice towards the right.

Each segment of EMR data was migrated into corrected positions along profile and ice thickness in metres. A simple geometric migration process is used assuming constant velocity through the ice ( $169 \mathrm{~m} /$ microsecond). After qualitative evaluation of the migrated data the accepted data were averaged within $100 \mathrm{~m}$ windows along the profile and if possible the standard deviation was calculated. EMR data were plotted as profiles at each step of the processing. Examples are shown in fig. 2.

The averaged, migrated ice thickness data were finally gridded using the program described in Thorning (1982); points along the actual ice margin with zero ice thickness were included in the gridding. The gridding method is based on the minimum total curvature principle of Briggs (1974). Two-dimensional Fourier filtering was then applied to the gridded data.

The gridded data ( 100 by $100 \mathrm{~m}$ ) were used as the basis for the contouring of the ice thickness map. Several versions of line countour maps and colour contour maps were produced in different scales for various purposes. The resultant ice thickness map is very satisfactory and shows a systematic variation. 

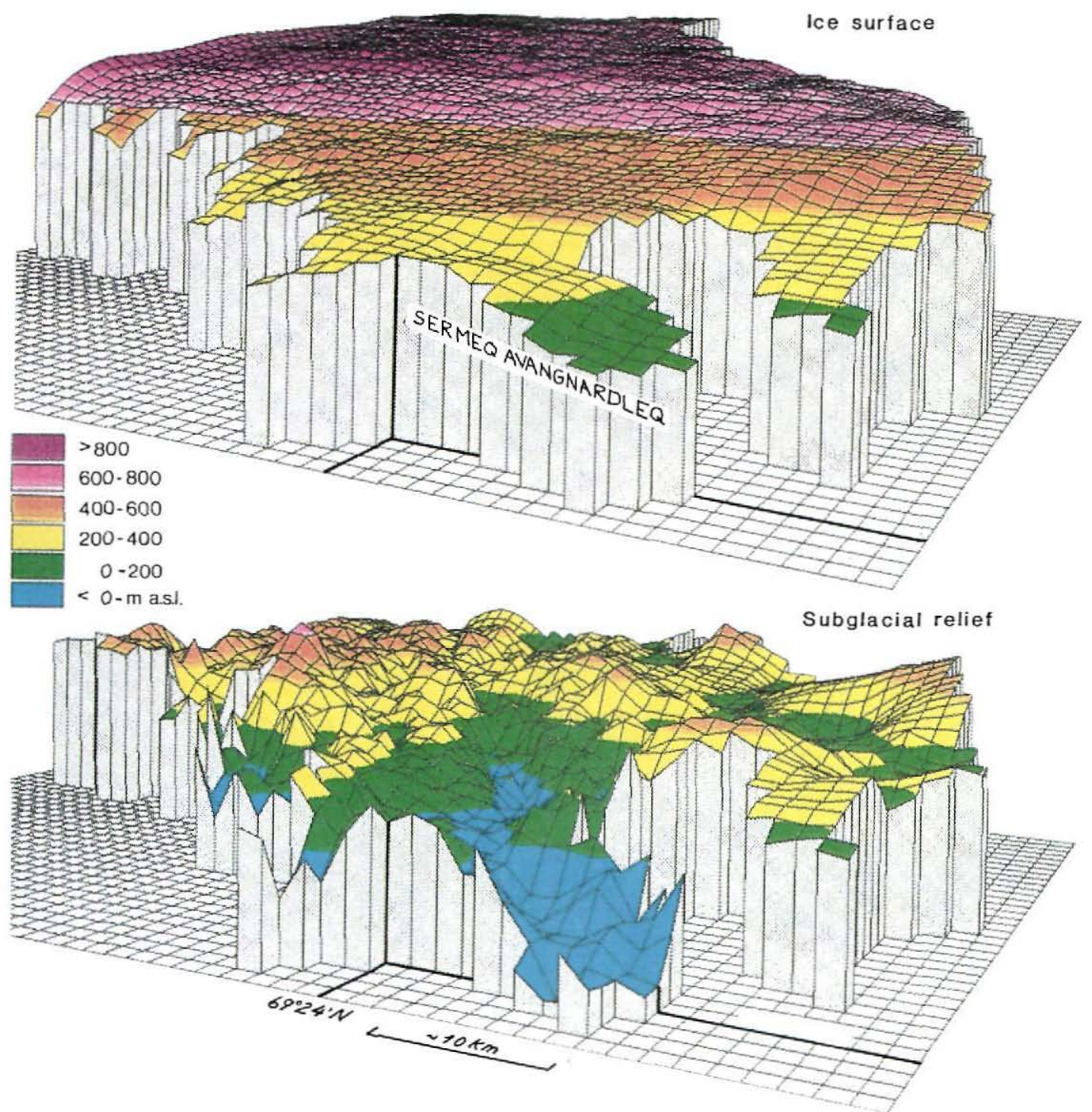

Fig. 3. Ice surface (upper) and subglacial relief (lower) in a three-dimensional representation. A simplified colour scale is used. Heights are in metres above sea level.

\section{Map of subglacial relief}

In order to produce a topographic map of the subglacial relief a detailed knowledge of the ice surface was required. This was obtained from aerial photographs from 1959, 1982 and 1985 through digitization of contours in GGU's photogrammetric laboratory (Thomsen, 1983). The surface from 1985 was used for the final map. The digitized contour data were 
transferred to the Danish Computing Centre, Copenhagen, and made available for GGU's gridding and contouring package there. The data were gridded using the same method and same grid dimensions as for the ice thickness data. Using another GGU program (GRIDOP) the two data sets were combined on a grid level to produce a grid of the subglacial relief.

In fig. 3 the 1985 surface and the subglacial relief are shown in a three-dimensional representation. The relief is substantial and ranges from $350 \mathrm{~m}$ below sea level to $650 \mathrm{~m}$ above sea level. The area is dominated by a valley system related to the large glacier Sermeq avangnardleq in the south-western part of the area and connected to the fjord at the head of the glacier.

\section{Maps of subglacial water potential}

For the glaciological evaluation a series of maps showing subglacial water potential has been calculated following Björnsson $(1982,1986)$ for various assumptions on the water pressure in the ice. Björnsson's formulae were transformed to a linear combination of the ice surface and ice thickness grids, and the GRIDOP program could then be used to calculate grids of subglacial water potentials (see Thomsen et al., 1986).

\section{Instrument improvements}

Parallel with the EMR surveying in Greenland and the processing and interpretation of the data, the equipment has been improved significantly by GGU, in cooperation with the Electromagnetic Institute of the Technical University of Denmark (DTH). Some of the improvements took place prior to the April 1986 operation, but most were incorporated later in preparation for future surveys. A summary of the instrument improvements and additions follows below.

During the operations in 1986 the video recorder used for the recording of EMR data developed instabilities which reduced the quality of the data. Therefore, a new portable video recorder (Sony V0-6800PS) was acquired. Besides being much better suited for field operations it also has two audio channels that can be used for navigational purposes and recording of comments during flights.

A new z-amplifier (transforms the amplitude trace to an intensity trace) has been constructed by Per Skov Madsen (DTH). This will produce more sharpely defined traces.

An event marker is being constructed that will record event numbers and the corresponding time, as well as a regular time signal on one audio channel. The encoding unit can also be used for other navigational signals.

A mono-pulse radar is also under construction by GGU following Hodge (1978) and will be completed in the spring of 1987 . This will be used for follow-up work on the Inland Ice and the glaciers where no signals could be obtained with airborne equipment.

\section{Reconnaissance EMR survey over Sarqardliup sermia}

The potential site of a hydropower plant for Christianshåb is an ice-damned lake, Tiningnilik, just south of Sarqardliup sermia. There is a risk that the high water level in the lake 


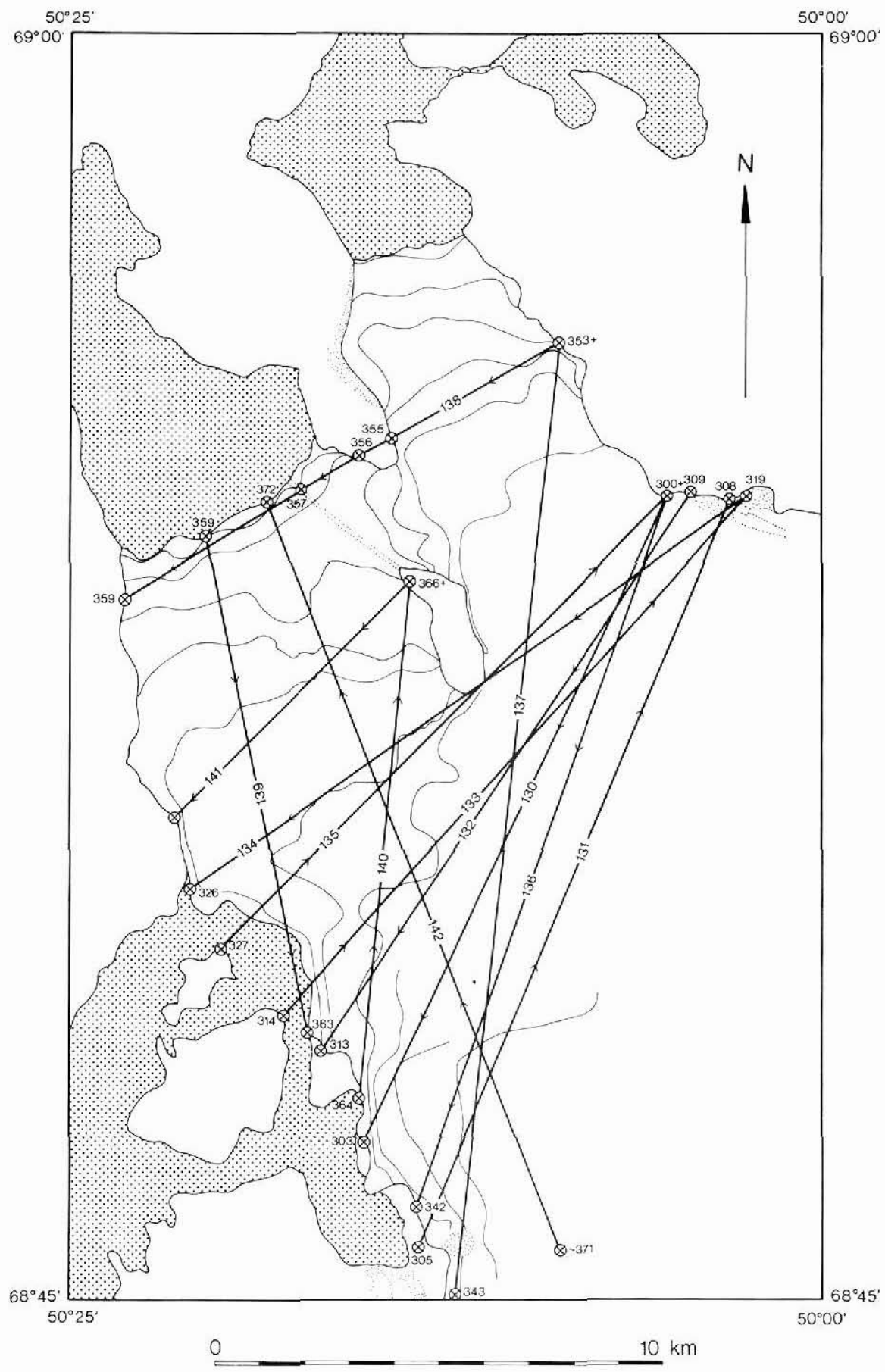

Fig. 4. Flight lines flown april 1986 over Sarqardliup sermia (southern glacier) and the Alalngardliup sermia north of Tinningnilik (hatched area in south-western part of figure). 
created by an artificial dam could lift the glacier off its bed and allow some of the water in the lake to drain under the glacier and thus leave the basin without producing any power. To evaluate this possibility a good knowledge of the shape and relief of the bedrock in the area under the border between the lake and the glacier is required. In April 1986 an afternoon was used for a reconnaissance survey over the glacier, with one stop in Christianshåb for refuelling. Fig. 4 shows the lines flown. No navigational systems were available in the area, and the lines were placed by visual sighting. Flight altitude was as usual $10 \mathrm{~m}$.

Although water in the glacier was at a minimum in April the scattering of the radar signals was worse over the glacier than over the ice cap itself. However, at most lines some reflections have been recorded over Sarqardliup sermia just north of the lake and over the upper part of Sarqardliup sermia. No data were obtained over the lower, broken-up parts of the glaciers. Ice thicknesses ranged from less than 2 micro seconds up to 5-6 micro seconds (two-way travel time).

The data have not yet been finally compiled and analyzed, but further airborne work is probably needed in the area including the Inland Ice itself east of the glaciers and the lake, and ground work with mono-pulse radar will be necessary in the vicinty of Tiningnilik.

\section{Future work}

The use of EMR data described in this note has been restricted to the basin-scale analysis related to the planned Pâkitsoq hydroelectric power plant. However, the data themselves and the methods developed during the course of this work have a potential for further use in a more detailed manner and there are other areas that need to be surveyed. Several further activities are planned:

(1) Improvements in the processing of EMR, e.g. the migration process.

(2) Follow-up work on the ice surface using a mono-pulse radar in the Pâkitsoq area near the planned site of ice borings and on the lower parts of glaciers.

(3) Detailed airborne EMR survey in the same region to map the subglacial relief in detail around the site of the ice borings.

(4) An experimental survey on the 'Amitsulôq' ice cap near Tasersiaq (Olesen, 1986) involving airborne and ground radar, magnetics and gravity, and the calibation of these techniques. This experiment should also include repeated measurements along the same profile at different times of the year to evaluate the influence of water on the radar measurements.

(5) A programme for EMR, surveying all parts of the margin of the Inland Ice influencing potential sites for future hydroelectric power plants.

Acknowledgements. The authors would like to acknowledge the cooperation and assistance of the following: P. Skov Madsen, Electromagnetic Institute (improvement of radar system), K. Frellevig, Programudvikling (development of new programs), B. Madsen, GTO (participation in 1986 field operation and calculation of navigational data), pilots and mechanics, Greenlandair Charter, M. Svane, D. Nyland Sørensen, GGU (digitization of EMR data and handling of many computer runs), GTO (financing of the navigation system used in 1986). 


\title{
References
}

Björnsson, H. 1982: Drainage basins on the Vatnajökull mapped by radio echo soundings. Nordic $\mathrm{Hy}$ drol. 13(4), 213-232.

Björnsson, H. 1986: Delineation of glacier drainage basins on western Vatnajökull. Annals Glaciol. 9, 19-21.

Briggs, I. C. 1974: Machine contouring using minimum curvature. Geophysics 39, 39-49.

Hodge, S. M. 1978: USGS Mono-pulse Ice Radar. Unpubl. intern. USGS rep., 10 pp.

Olesen, O. B. 1986: Fourth year of glaciological field work at Tasersiaq and Qapiarjiup sermia, West Greenland. Rapp. Grønlands geol. Unders. 130, 121-126.

Thomsen, H. H. 1983: A glaciological field and mapping programme in connection with hydropower, West Greenland. Rapp. Grønlands geol. Unders. 115, 102-107.

Thomsen, H. H., Thorning, L. \& Braithwaite, R. 1986: Vurdering af de gletscher-hydrologiske forhold på Indlandsisen ved Paakitsup Akuliarusersua, Ilulissat/Jakobshavn. Arbejdsnotat. Geol. Surv. Greenland, $82 \mathrm{pp}$.

Thorning, L. 1982: Processing and interpretation of aeromagnetic data in The Geological Survey of Greenland. Rapp. Grønlands geol. Unders. 114, 41 pp.

Thorning, L., Thomsen, H. H. \& Hansen, E. 1986: Geophysical investigations at the Inland Ice margin of the Pâkitsoq basin, central West Greenland. Rapp. Grønlands geol. Unders. 130, 114-121.

\section{The last full summer of glacier-climate investigations at Qamanârssûp sermia, West Greenland}

\author{
Roger J. Braithwaite
}

As part of the GGU programme of hydropower investigations in West Greenland, glaciological and climatological measurements were continued at Qamanârssûp sermia in 1986. The station was first established in the late summer of 1979 so that records for seven complete summers 1980-1986 are now available. Brief reports on the work have been given by Olesen (1981), Olesen \& Braithwaite (1982), Braithwaite (1983a, 1984, 1985a, 1986a). More detailed analyses and presentations of data are given in Braithwaite \& Olesen (1982) and Braithwaite (1983b, 1985b).

According to present plans, the Qamanârssûp sermia station will not be manned again for a full summer as it has been for the last seven years. However, a reduced programme of measurements will be continued in future years. A brief discussion of future plans is given at the end of this report.

\section{Field work 1986}

When the first field party arrived in the area in late May, there was obviously more snow accumulation on the glacier than usual. However, from talking to people in Nuuk, and from observations in snow pits, it was obvious that most of the snow was of recent origin, i.e. from 